University of Texas Rio Grande Valley

ScholarWorks @ UTRGV

\title{
The Only Thing That Stops a Guy with a Bad Policy is a Guy with a Good Policy: An Examination of the NRA's "National School Shield" Proposal
}

Gordon A. Crews

The University of Texas Rio Grande Valley, gordon.crews@utrgv.edu

Angela D. Crews

Catherine E. Burton

Follow this and additional works at: https://scholarworks.utrgv.edu/cj_fac

Part of the Civil Rights and Discrimination Commons, Criminal Law Commons, Criminology and Criminal Justice Commons, and the Education Commons

\section{Recommended Citation}

Crews, G.A., Crews, A.D. \& Burton, C.E. The Only Thing That Stops a Guy with a Bad Policy is a Guy with a Good Policy: An Examination of the NRA's "National School Shield" Proposal. Am J Crim Just 38, 183-199 (2013). https://doi.org/10.1007/s12103-013-9202-x

This Article is brought to you for free and open access by the College of Liberal Arts at ScholarWorks @ UTRGV. It has been accepted for inclusion in Criminal Justice Faculty Publications and Presentations by an authorized administrator of ScholarWorks @ UTRGV. For more information, please contact justin.white@utrgv.edu, william.flores01@utrgv.edu. 
The only thing that stops a guy with a bad policy is a guy with a good policy: An examination of the NRA's "National School Shield" proposal

Gordon A. Crews, Marshall University

Angela D. Crews, Marshall University

Catherine E. Burton, The Citadel

Corresponding Author

$$
\begin{gathered}
\text { Gordon A. Crews } \\
\text { Marshall University } \\
\text { Department of Criminal Justice \& Criminology } \\
\text { One John Marshall Drive } \\
\text { Huntington, WV 25755 } \\
\text { 304-696-3083 } \\
\text { crewsg@marshall.edu }
\end{gathered}
$$




\begin{abstract}
With the recent tragedy at Sandy Hook Elementary in Newtown, CT, the public and the government are looking for solutions to school violence. The National Rifle Association (NRA), a second amendment, pro-gun advocacy group, has proposed an "education and training emergency response program" called The National School Shield, which advocates the placement of armed security in schools. Although the program sounds provocative, serious questions complicate its plausibility, necessity, motive, and effectiveness. Furthermore, the potential policy and practical ramifications of encouraging armed security forces in U.S. schools are complex. The authors examined the proposal's key elements from a public policy perspective and determined that the NRA program would be expensive in terms of both implementation and civil and/or criminal liability, would increase juvenile contact with the criminal justice system, would increase the potential for injuries and deaths from firearms, and would potentially only serve to increase profits for those invested in security industries. More potentially effective and safe policy alternatives are offered.
\end{abstract}




\section{Introduction}

The NRA wants the public to believe that schools are not safe places to send children (Hutchinson, December 23, 2012). This is currently becoming a widespread belief due, in part, to speakers like Lt. Col. (ret.) Dave Grossman, developer of "killology," who proclaimed in a recent address to the West Virginia Safe Schools Summit that school violence is the "leading cause of death" of children (Grossman, 2013).

Both claims are flat-out untrue. To refute Grossman's claim, unintentional injury is the leading cause of death among ages 5-24, although homicide $i s$ the second leading cause of death among ages $15-24$. While homicide by firearms is the leading cause of violence-related injury death among ages 5-9 and 15-24, nearly all of these deaths occurred away from schools (Centers for Disease Control and Prevention, 2010).

Contrary to the NRAs claim, school violence is decreasing (Robers, Zhang, Truman \& Snyder, 2012) and "schools are the safest place for a student to be" (Brock, as cited in Neuman, 2012). From 2009 to 2010, 33 violent deaths of students, staff, and non-students occurred at schools. Of these, 17 school age youth (ages 5-18) were victims of homicide and 1 was a victim of suicide. These figures represent the lowest number of total violent deaths since 1992 (when this started being measured), the lowest number of student deaths since 2001-02, and the lowest number of suicides since 1996-97. In fact, during the 2009-10 school year, there was only about 1 homicide or suicide of a school age youth at school for every 2.7 million students enrolled (Robers et al., 2012).

School-age youth are much more at risk of violent death away from school. The most recent available data indicate that, since 1992 , less than $2 \%$ of youth violent deaths have occurred at school (National Center for Injury Prevention \& Control, 2012), which means that 
more than $98 \%$ occurred elsewhere. When rape, sexual assault, robbery, and aggravated assault are considered, rates at school in 2009-10 (4 per 1,000) did not statistically differ from those occurring away from school (5 per 1,000).

Tragic incidents of school violence like the one at Sandy Hook Elementary School in Newtown, CT on December 14, 2012, however, add fuel to the fire regarding school violence. Naturally, a shooting that claims the lives of 20 children and 8 adults (including Adam and Nancy Lanza) at a place where millions of people send their children every day results in numerous calls for action. The majority of those calls revolve around two major areas- gun control, and additional security measures for schools, including the use of armed security personnel.

Those who advocate gun control measures focus primarily on the background check process and loopholes in background checks related to the purchase of weapons from places other than authorized dealers (e.g., gun shows), and on the availability of assault weapons and high capacity magazines. Although school security includes several types of procedural tactics, such as controlling access to school grounds and/or school buildings, metal detectors, requiring visitors to sign-in, telephones in the classrooms, and security cameras to monitor the school, those who advocate additional security measures as a solution focus on the placement of trained, armed personnel in every school. This is the primary feature of The National School Shield program proposed by the NRA.

\section{Policy Implications and Practical Ramifications of The National School Shield Proposal}

At a December 21, 2012 news conference, Wayne LaPierre, CEO and Executive Vice President of the NRA, introduced former Congressman and former Director of the Drug Enforcement Administration (DEA) Asa Hutchinson, to give a brief overview of the program 
(LaPierre, 2012). This overview mentioned "two key elements" which would be guided by his "team of experts." Those two key elements are the development of a model security plan, and the use of community volunteers as armed security.

\section{Team of Experts \& Model Security Plans}

Given the scope and potential impact of the NRA proposal, and the fact that it involves children on a national level, it is essential to carefully examine its components. First, Hutchinson discusses a "team of experts," but does not describe who would comprise this team, how they would be selected, or who would evaluate their level of expertise. This team is supposed to take the lead in fleshing out, developing, and implementing a proposal to address a complex, multifaceted issue involving the lives of millions of children and adults

Apparently, these individuals will be developing "model security plans" for schools to follow, and consulting with school officials, law enforcement officials, and parents all across the United States, although it is unclear who will pay these experts for their services and how much it will cost. One major concern is the real probability that these experts may have conflicts of interest because they could benefit financially and politically if schools adopt their programs and purchase equipment and manpower required for program implementation. These potential conflicts of interest are discussed below.

\section{Use of Trained, Armed Security Personnel \& Community Volunteers}

The model security plan consists of a "comprehensive strategy for school security based on the latest, most up-to-date technical information from the foremost experts in their fields" (Hutchinson, 2012). Part of this plan is the use of "armed, trained, qualified school security personnel," but Hutchinson notes that this would be "a decision to be made by parents at the local level" (2012). 
Hutchinson has publicly advocated the idea of placing trained guards to staff the proposal and emphasized that untrained guards should not be placed in schools. Supporting Hutchinson's position, a recent Gallup poll indicated that the majority of Americans surveyed, regardless of political affiliation, believe that placing armed officers at schools is the answer to school shooting tragedies (O'Brien, 2012).

\section{Insert Table 1 About Here}

Hutchinson is not the first to suggest armed guards in schools. It became a popular idea after the Columbine shooting in 1999, and currently, approximately $27 \%$ of schools in the U.S. have some sort of daily police or security presence (Snyder \& Dillow, 2012). Richland County, South Carolina, for example, has armed "Resource Officers" at all its middle and high schools, while elementary schools have one officer for every two schools. Officer salaries are shared by the school district and Richland County Sheriff's Department (Rich, 2012).

However, concerns similar to those over the selection of the "team of experts" also surface with respect to the selection of the "armed, trained, qualified school security personnel." Hutchinson has offered no elaboration on whether these personnel will be certified bonded police officers who will assume these tasks as part of their official details, "moonlighting" police officers who will work at schools "off-duty," retired police officers or military, private security officers, existing school personnel (i.e., armed staff, teachers and/or administrators), or parents or other community volunteers.

The selection, verification of qualifications (e.g., background checks; proficiency with firearms), training, and certification of these individuals is critical, yet Hutchinson has offered no insight into these processes or who will do them. It also is unknown what weapons these 
personnel will use or have access to, or where and how those weapons will be stored and maintained. Each of these concerns involves myriad liability issues which are addressed below.

Although Hutchinson emphasized that having armed security personnel is not the only element of the plan, he did not elaborate on any other component. LaPierre, in his introductory remarks, described a "multi-faceted program . . .developed by the very best experts in their fields" consisting of everything from "building design and access control to information technology to student and teacher training" (LaPierre, 2012). These hints of additional programmatic aspects raise more questions about responsibility. It is an expensive endeavor to design, modify, or construct a building. It also is expensive to update, install, or augment information systems, or to modify, install, supplement, or change security systems. In 2006, Education Department analysts in Connecticut estimated that a multiple camera security system with a "buzzer" entry, scan cards, a "duress" alarm system with panic buttons, and a portal metal detector with two trained security personnel for a large high school could cost up to $\$ 480,000$ (Lohman \& Shepard, 2006). This would be much higher in 2013 dollars.

Someone will be hired to do build or modify buildings, to install or update security systems, and to provide metal detectors. Someone will be selected to provide (i.e., sell) equipment, supplies, hardware, and software. Someone will be hired to monitor and maintain all of the equipments, systems, hardware, and software. Someone will be hired to train and equip personnel. Conveniently, "the National Rifle Association is the natural, obvious choice to sponsor" the program (Hutchinson, 2012). Of concern, however, is such a seemingly readymade provider of all things necessary for the level of school security required for the safety of children. Clearly, conflicts of interest abound. 
The second key element is the use of community volunteers to avoid "massive funding from local authorities or the federal government" (Hutchinson, 2012). Setting aside the issue of funding for the moment because LaPierre (2012) declared in his introduction that Hutchinson would have a "budget provided by the NRA of whatever scope" required, allowing armed community volunteers to have such intimate access to children and school personnel would seem to increase the risk of harm.

Requirements for background checks of those involved with public schools vary widely from state to state. While 25 states and the District of Columbia require criminal history checks for all public school employees, only 5 require such checks of all contractors, and only 8 require checks of individuals that volunteer (Government Accountability Office, 2010). When checks are required, "they may not be adequate because they are not national, fingerprint-based, or recurring" (GAO, 2010, p. 6). Moreover, many states have no restrictions on employing former sex offenders.

Even when background checks are conducted, people with bad intentions can sometimes make their way to positions of power and authority. For example, in 2010, the owner of a security company and chief of security for a public school district in Wyoming, Michigan, was charged with 2 counts of criminal sexual conduct after using his position to have sex with a then14 year old girl on at least 2 occasions (McCann, 2010). During the first 44 days of 2013, the following 22 criminal incidents involving security guards or officers have been reported on Private Officer News Network (privateofficernews.wordpress.com):

- security guard in Newport News, VA arrested for home burglary

- security guard in St. Augustine, FL arrested for burglary, theft, exploitation of the elderly

- security guard in New Orleans, LA arrested for illegal use of a weapon

- security guard on probation in Redding, CA arrested for meth possession, possession of an unlawful weapon, possession of ammunition by a felon, and felony probation violation 
- security guard in Jackson, TN arrested for felony vandalism after destroying Jewish artifacts

- security officer in Murrells Inlet, SC arrested for shoplifting

- school security guard in Homestead, FL is under investigation for sexual assault

- school district Security Supervisor and former police sergeant in Wichita, KS arrested for indecent liberties with a child and criminal sodomy

- security guard in Orange County, FL arrested for shining a laser at a sheriff's helicopter

- armored car driver in Bryan, TX arrested for armed robbery

- security guard in Memphis, TN arrested for attempted murder

- campus security guard in Middletown, CT arrested for a string of felony thefts

- Walt Disney World security guard in Davenport, FL arrested for 8 counts of possession of child pornography

- security guard in Spring Hill, FL arrested for credit card fraud

- middle school security guard in Little Rock, AR arrested for 2 counts of second degree sexual assault

- 2 TSA officers in Atlanta, GA arrested for conspiring to smuggle drugs

- a security guard in Atlanta, GA, with a history of mental illness, convicted of murder

- a State Department security officer in Alexandria, VA convicted of accepting bribes

- a school security guard in Tacoma, WA arrested for 3 counts of first degree sexual misconduct with a minor

- 2 security guards in Memphis, TN arrested for aggravated assault

- an unarmed school security guard in Garfield, NJ arrested for impersonating an officer, possession of a weapon without a permit and possession of a weapon on school property

- security guard at a middle school in Little Rock, AR arrested for second degree sexual assault involving a minor

If security guards are placed in every school in the United States, it is frightening to think how this problem would be exponentially magnified. Using local volunteers would seem to exacerbate the potential for unqualified, criminal, and/or ill-intentioned individuals to take advantage of such unique, and potentially unsupervised, access to children. Allowing more people into schools will give more people access to the children. If a child is harmed by an overly zealous armed security member or sexually assaulted by a pedophile that has slipped through the system, someone would have to be held liable. This very real potential is not worth the risk of hiring community volunteers who may not be subjected to thorough national-level, 
fingerprint-based background checks that are repeated on a regular basis, especially when officers who have been through such checks commit crimes such as the ones listed above.

Hutchinson described a program at his son's school in his home state of Arkansas, where 2 of the 22 criminal incidents above occurred at middle schools, called "Watchdog Dads." In this program, fathers of school children "volunteer their time at schools to patrol playgrounds and provide a measure of added security" (Hutchinson, 2012). Although Arkansas is one of the few states that does require national, fingerprint-based background checks on all teachers and on all non-licensed personnel (GAO, 2010), this is a rarity, and apparently people with ill intent still slip through. Hutchinson implies the NRA program would function similar to this program except that the dads would be armed. However, simply being a parent of a child confers neither the right, nor the ability, nor the responsibility to oversee others' children.

Hutchinson concluded his second key element by offering the assurance that "whether they're retired police, retired military or rescue personnel, I think there are people in every community in this country, who would be happy to serve, if only someone asked them and gave them the training and certification to do so" (Hutchinson, 2012). In difficult economic times and increased public fear, people often will turn to anyone or anything for help. When available options seem to be essentially "free" in the reality of dwindling school budgets, they are very attractive. Moreover, when those options seem to alleviate external pressures, such as parental fear, they become almost impossible to turn down. Will, and more importantly, can schools, in their desperation to protect children and alleviate parental and public fear, be vigilant enough to know who they are trusting with access to their children?

Hutchinson asserts that the NRA's "gun safety, marksmanship and hunter education programs have set the standard for well over a century," and that "over the past 25 years, their 
Eddie Eagle Gunsafe Program has taught over 26 million kids that real guns aren't toys and today, child gun accidents are at the lowest levels ever recorded" (Hutchinson, 2012). However, this assurance does not negate the potential issues that would arise if the NRA does become responsible for the training of most, if not all, of the armed security officers under this plan. The NRA is still a private organization with very little, if any, governmental control or oversight. Currently, those who participate in their training programs do so willingly and accept any liability or injury that may occur to themselves or others they encounter. If their training becomes mandated to some, they must accept the inherent liability which comes with training for those who will serve the public in such a crucial and dangerous role. The potential for that liability looms large for anyone who "certifies" that another person knows how, and more importantly, when to fire a weapon. The school environment simply exacerbates this potential problem.

\section{Responsibility and Liability Issues}

The success of the NRA proposal rests on the assumption that putting more guns in schools will keep guns out of schools. LaPierre argues that Gun-Free Zones are an "invitation to mayhem," to those wishing to harm children (Sullivan, 2012). These zones are well-advertised to inform everyone coming onto school property that all firearms, except those carried by security personnel, are banned on school property, and that anyone violating that policy can be arrested. LaPierre believes that these zones are places where potential perpetrators are guaranteed access to large numbers of children with little or no chance of being confronted by anyone with a weapon and he uses this as a foundation for the recommendation that all schools have armed security. In essence, LaPierre recommends that problems stemming from weapons can be solved by weapons (LaPierre, 2012). 
This concept has a serious potential flaw. The presence of armed security means the presence of weapons. Law enforcement officers are taught to remember that even if they encounter someone without a weapon, a weapon is still present, theirs. Even schools that are truly successful in preventing students from bringing weapons onto school grounds will still have weapons if armed security is present. Students may have their cars searched in the school parking lot, have their persons searched at the school entrance, and have their lockers randomly searched to prevent them from carrying a weapon on school property. However, those same students will know that they do not need to bring weapons to school, weapons will be there. The only remaining question at that point is how to obtain one of those weapons. It is easy to imagine that the more desire a student has to obtain a weapon, the more violence that student will generate to obtain it.

Another concern is the potential liability that is involved with increasing the risk to children, to staff, and to the security officers themselves. If sworn police officers provide this security as part of their duty assignment, then the liability is assumed by that police jurisdiction. "Moonlighting" officers, who would be providing security "off-duty," outside of their normal job requirements, would likely not be covered and either the school district or the officer would have to purchase supplemental liability insurance. Luckily, retired police officers can purchase up to $\$ 250,000$ of "retired law enforcement officer self-defense coverage," provided by the "NRA Endorsed Property \& Casualty Insurance Program" and administered by Lockton Affinity, LLC (http://www.locktonrisk.com/nrains/retiredofficer.htm), but it is not clear whether this insurance would cover the retired police officer who chose to take a position providing security for a school. Individuals who are hired and trained by private security providers would be insured against liability by the agency. It is unclear whether any liability insurance would cover trained, 
armed community volunteers, but if it would, the cost of that insurance would most likely be borne by the individual or by the school district and this cost could quickly become prohibitive.

Numerous scenarios become evident when thinking about the potential liability of those placed in school security positions. Even firing on a would-be school shooter trying to enter a school would likely bring civil suits from that person's family. In addition, if a shooter happened to make it past security, even more significant liability issues arise. If an innocent bystander is injured or killed by that security person or if the security person does not act quickly enough and the shooter injures or kills students or staff, that officer can potentially be held liable. These are all scenarios that any school district hiring security staff must consider.

In addition to liability related to those the security is intended to protect, the security personnel are at risk of injury or death. In 2012, 112 private security officers died or were killed on-duty; $58 \%$ of the officers died from shootings, $13 \%$ from trauma, $8 \%$ from stabbings, and the remainder from medical issues, industrial or car accidents, and drowning. Overall, more than 70,000 incidents were reported involving private security officers as the targets of violence (verbal and physical assault) (Private Officer International, 2013). Between January 1 and February 11, 2013, 14 deaths of private security officers were reported (Private Officer International, 2013), but it is not clear how many of these officers were armed.

As more schools add more armed security, and as schools establish armories full of high powered weapons which are to be immediately available in emergencies, the potential risk and liability exponentially increases. Individuals who carry these weapons must know how to use them, when to use them, and how to maintain control of them. More weapons in schools, no matter who has them, the more chances for them to fall into the wrong hands and be used 
unsafely and/or unlawfully. There is always inherent liability and danger for those who carry guns as well as those who allow them to be carried.

\section{Insert Table 2 About Here}

\section{Impact on Individual Freedoms and Choice of Employers and Employees}

Another area of potential conflict is the freedom of choice of those involved either directly by being required to carry a weapon or peripherally by having to conduct daily business with colleagues who are armed. This is evidenced in many jurisdictions who are already implementing programs similar to the one proposed by the NRA. While the NRA proposal does not recommend that school administrators, teachers, and staff be armed, many schools are allowing their teachers, principals, and/or custodial and maintenance staff to bring concealed weapons to their campuses (McKinley, 2008), and several states are currently considering legislation that would allow this (e.g., Colorado, Michigan). As of January 15, 2013, 18 states allow adults to carry firearms on school grounds with written permission from a principal or school board (Huffington Post, 2013).

Numerous recent surveys of educators in K-12 schools have offered a glimpse into what American teachers may be thinking with respect to the issue of more guns in their schools. Teachers in Connecticut, for example, "overwhelmingly oppose having its workforce carry guns on campus" (Thomas, 2013), and 67\% of teachers in California believe hiring a counselor would be more effective at preventing school violence than hiring a police officer (McGreevy, 2013). Various teachers unions, such as the one in Fairfax County, Virginia, voice similar concerns, with more than $60 \%$ of the union members in that county saying they did not want guns in schools (Hendry, 2013). The majority of surveys and polls indicate that most teachers do not want teachers, staff, or administrators carrying guns, and especially do not want to carry one. 
School boards, however, may have different perceptions which could lead to tension between teachers and district administrators.

Kenneth S. Trump, President of National School Safety and Security Services, "advises against arming teachers and school staff" and outlines at least 9 considerations, many related to civil liability, for schools considering arming teachers or other staff (National School Safety and Security Services, 2013). Civil suits, and possibly charges of criminal negligence against school districts are likely when those districts assume responsibility for the actions of teachers who are required to carry weapons or who are forced to interact closely with others who carry weapons. This would not be an inexpensive undertaking.

Parents and other community members also have a say and the NRA proposal is getting mixed reviews (Zagorski, 2012). LaPierre and Hutchinson both stated that the choice of whether a local school will have armed security (whatever that may mean) is a choice to be made by local parents. Theoretically, this is plausible, but practically, it could be a logistical nightmare. Given the amount of national debate generated immediately following any shooting at an American school, it is safe to assume that those debates at the local levels could become heated.

Obviously, these decisions will reflect popular opinion at the local levels, but that might not be smart policy. With this type of potentially litigious decision, it is probably not advisable to let majority rule on a decision that will impact the lives of everyone from the students to the teaching faculty to the staff to the parents. If the parents decide to allow armed faculty, the school district will ultimately be responsible for suits and criminal charges arising from bad choices or accidents that injure or kill someone. 


\section{The Profit Motive}

Some estimate that funding the NRA proposal will cost $\$ 4$ to $\$ 6$ billion, while Hutchinson puts forth a more conservative estimate of $\$ 2$ to $\$ 3$ billion. Either estimate means huge potential profits for private security companies (Murphy, 2012; O’Brien, 2012). Although LaPierre (2012) declared in his introduction that Hutchinson would have a "budget provided by the NRA of whatever scope" required, this budget most assuredly only refers to plan development and not implementation. Implementing the plan would certainly fall to school districts requiring them to use local and/or state tax dollars to recruit trained, armed volunteers, to recruit volunteers that they must train and arm, to hire trained, armed private security, or to divert public law enforcement services. Except for using public law enforcement, each of the above options would require training and/or personnel, which would necessitate the involvement of entities that provide security training and/or personnel.

If school districts contract with existing private security agencies, which is one of the least costly options, the quality of protection may be at stake. Although private security contractors have widely been used in many government sponsored initiatives, such as the wars in Iraq and Afghanistan, more experienced contractors have complained that the pool of security officers has been diluted by lowered qualifications, which has led to decreased salaries and benefits (Kelly, 2011). In any private endeavor, profit is an inherent factor. Profit may or may not be achieved at the sacrifice of quality, but there is less regulation and recourse in the private security industry than in government agencies.

In addition to the potential financial boon for the security industry, other industries stand to profit handsomely. With the movie theater shooting in Aurora, Colorado, and the school shooting in Newtown, we see various products making their way to the marketplace promising 
parents that their children will be safer. For example, a company is offering bullet-proof backpacks (Dewey, 2012). Sales of the backpacks soared to such a level after the Newtown shootings that their website crashed at least once (CBSLA.com, 2012). The effectiveness of such products seems to be lost in the fear many have after such tragic incidents. Students often are prohibited by school policy from wearing their backpacks during the day, so the actual practical protection is little and the backpacks can only stop the types of ammunition used in some of the shootings. Furthermore, statistics indicate that schools are very safe and that the psychological presence of armed guards and these kinds of products being offered via the security industry can have damaging psychological effects (Dewey, 2012; Jennings, Khey, Maskaly, and Donner, 2011).

\section{The Line Between Public and Private Becomes a Slippery Slope}

It has been 12 years since the Columbine school shooting tragedy and the United States is no closer to an effective solution for school violence. Columbine spurred the nation to implement zero tolerance policies, video surveillance, and armed guards or police officers in schools. The research to date is sparse, but some of the studies indicate that the efforts have been counterproductive in that they have yielded decreased attendance as well as an increase in arrest for minor offenses (Skiba, 2012; Jennings, Khey, Maskalay, and Donner, 2011).

If the U.S. follows the NRA proposal and insists that every public school have an armed officer, it is hard to know where the line will be drawn if it is followed to its logical conclusion. School bus violence, for example, has increased in recent years (Lang, 2005). Perhaps buses that provide transportation also will be required to have surveillance systems and armed drivers or guards. Additionally, school yards and playgrounds, where violence has been known to take place, are open territories with little protection or surveillance. Prohibiting outdoor activities or 
providing guards in watchtowers would turn schools into prison-like environments instead of environments conducive to learning.

Implementing security ideas from fields that have an impact on school safety is possible. Architecture, for example, has long been contributing to school security in terms of designing and building educational structures that are both aesthetically pleasing and safe (Halbig, 2008). Security measures have been incorporated into school design since Columbine, but many currently are calling for an examination of how additional security measure can be incorporated into education venues.

Again, balance may be the key. Numerous architectural features may assist in school safety without turning schools into prison-like fortresses. Some examples are single school entrances, automatically locking doors, reduced landscaping, relocating restrooms away from the entrance, creating a separate entrance for employees, and designating lanes in front of school entrances to only be accessible by buses (Crow, 2000; Gubrecht, 2012).

It is not possible to prevent all school shootings, even with additional security measures. An examination of the security policy at Sandy Hook Elementary would probably reveal that school officials responded appropriately and could not have prevented the shooting, regardless of police presence or additional architectural security measures. The U.S. secures airports and courthouses as government-run public spaces, but a worrisome question about the potential extent of these security precautions is whether these measures eventually will be forced upon privately owned public spaces. Some shopping malls, for example, often provide small private security forces, but if the NRA policy is implemented in schools, other public places may be pressured to follow suit. 
Many advocates of the NRA policy point to Israel as an example of a country that places armed guards in all schools. Israel also places armed guards at restaurants, malls, parking lots, and many other public spaces (Associated Press, 2012). If Israel is the role model for successful school security policy, other areas may follow. The U.S. and Israel, however, differ in two fundamental ways regarding gun control. First, Israel has strict gun laws and does not guarantee the right to bear arms under its constitution. A gun license in Israel requires several layers of screening and renewal every three years, which is not automatic. Second, Israel requires every able citizen to serve a term in the military, which teaches the proper use of firearms. Even Israeli military personnel who use guns while serving still have to apply for licenses to keep guns as private citizens and are subject to the same renewal policy as any other citizen (Associated Press, 2012). Israeli officials have said that the actions proposed by the NRA are not comparable to Israel's. In fact, Israeli officials contend that they have armed guards at schools as part of their comprehensive strategy to combat terrorism and do not recommend the NRA policy given that school shootings are not linked to national security in the U.S. (Associated Press, 2012).

\section{Conclusion}

The resolution to school violence, especially mass shootings like the ones at Columbine and Newtown, is not simple. The NRA, however, proposes a superficially simple solution in its National School Shield program with armed security personnel comprised of community volunteers with implementation funded primarily by local dollars. Preventing school violence by focusing on the symptom of the problem is not the answer. As many emphasized after Newtown, the problem is troubled students, many who have suffered from significant mental health issues, behavioral disorders, and the systemic neglect of parents and teachers (Newman, 
2004). The availability of weapons, especially assault-type weapons compounds the issue (Crews \& Crews, 2013).

To prevent school violence, society must first address troubled youth who have easy access to weapons. Although scholars have been reluctant to develop any "profile" of school shooters, case studies have found that many had known or suspected mental health issues, family dysfunction, school problems, and social isolation, not necessarily as "loners," but perhaps in small, close-knit groups of “outsider” youth (Crews \& Crews, 2013; Newman, 2004). In many cases, but not all, the shooter had been bullied. Many had problems with just one or two students and several shooters recently had experienced the end of a close relationship. Depression and planned or completed suicide was common. Several living school shooters had initially planned only to kill themselves at school, but ended up feeling cornered and that they had nothing to lose by taking others with them (Crews \& Crews, 2013). More shooters have killed themselves (suicide or "suicide by cop" during or immediately after the incident, or suicide while incarcerated) than currently are alive (Crews \& Crews, 2013). Finally, nearly all shooters had told one or more peers or adults about their plans (Crews \& Crews, 2013; Newman, 2004). When concerned friends did report to an adult, they were not taken seriously or the reports were made too late.

It is unclear whether armed guards prevent school violence. In fact, a recent study found the presence of armed guards in New Orleans schools to be correlated with higher rates of school violence (Jennings, Khey, Maskaly \& Donner, 2011). It is even less clear whether an armed security force comprised of community volunteers would prevent school violence.

According to the most recent data (2007-2008), 27\% of elementary and secondary schools in the United States have daily police or security presence (Snyder \& Dillow, 2012), 
although it is not readily ascertainable what percentage are armed. In fact, armed guards were employed both by Columbine High School and Virginia Tech, where two of the most deadly school shootings have occurred. Security involved in one recent incident claims that a shooting was interrupted by an armed officer before it resulted in serious injuries or deaths. At least 5 people, however, were shot or injured by flying glass at Granite Hills High School near San Diego when an El Cajon police officer shot and immobilized the student, 17 year old Jason Hoffman, before he could enter the building (Moore, 2012). Hoffman succeeded, after two failed attempts, in hanging himself in jail while he awaited sentencing (Perry, 2001).

On the other hand, it is clear that schools with armed security have their students arrested or detained at nearly five times the rate of schools without armed guards (Shen, 2013). Students, who would be made to serve detention or suspended for a few days in schools without armed security, are going to juvenile detention or adult jail for behaviors ranging from disorderly conduct to violating the dress code.

Moreover, black students are more likely to be arrested. In October, 2012, the U.S. Justice Department filed a suit against the City of Meridian, Lauderdale County, and the Mississippi Division of Youth Services alleging that armed guards at their schools routinely violated the due process rights of children, particularly of black and disabled students. Armed officers are accused of handcuffing, detaining, arresting and incarcerating students without informing of their rights, without timely probable cause hearings, and without legal representation, for minor offenses such as school disciplinary infractions (Department of Justice, 2012).

President Obama has called for $\$ 155$ million for mental health services and to develop police/school partnerships, $\$ 150$ million for school districts to train teachers and staff, to hire 
"school resource officers," psychologists, counselors, and social workers, and to upgrade security equipment and emergency plans, \$50 million for staff and teacher training, and \$30 million in one-time grants to assist school districts in developing and implementing emergency plans (Gray, 2013). Although $\$ 385$ million sounds like a lot of money, it is just a drop in the bucket.

A hypothetical state with only 1 high school in each of its 140 districts would spend about $\$ 555,000$ per school, or a total of $\$ 77.7$ million on enhanced security systems with cameras, access-control systems, duress alarm systems, safety film, and on one security officer per school per year (Lohman \& Shepard, 2006; Gray, 2013). The \$385 million, then, would not go very far, covering only about 5 states (given the above scenario). Although helpful, these funds would have to be supplemented by significant local, state, or private funding (e.g., the NRA).

Preventing school violence does not have to be expensive. All it takes is preventing the development of young men and women into perpetrators of school violence, and putting armed guards at fortified schools will not do this. It requires the development of early recognition programs run by individuals trained to spot warning signs and situations that are correlated with violence. It requires the development of intervention programs staffed by professionals trained in defusing potentially violent situations and addressing those correlates, whether they are mental health problems, family issues, bully issues, relationship issues, conflict resolution issues, or self-esteem issues. In other words, it just requires someone to pay attention, to listen, and to care, which really cost nothing. 


\section{References}

Associated Press (2012, December 24). Israel rejects NRA's guns-in-schools claim. The Times of Israel. Retrieved from http://www.timesofisrael.com/israel-dismisses-us-gun-lobbysinaccurate-claim-about-gun-laws/.

Bardol, D. (2012, December 28). Putting armed guards in schools send the wrong message. The Baltimore Sun. Retrieved from http://articles.baltimoresun.com/2012-1228/news/bs-ed-schol-shootings-20121227_1_gun-control-debate-gun-sales-gun-violence

Bloomberg Businessweek (2013). W. Asa Hutchinson. Retrieved from http://investing.businessweek.com/research/stocks/private/person.asp?personId=2085598 2\&privcapId=2158476\&previousCapId=6529009\&previousTitle=Pinkerton\%20Govern ment $\% 20$ Services, $\% 20$ Inc.

CBSLA.com. (2012, December 19). Sales of bulletproof backpacks soar after school shooting. CBS News. Retrieved from http://losangeles.cbslocal.com/2012/12/19/sales-ofbulletproof-backpacks-soar-after-school-shootings/.

Center for Responsive Politics (2013). Asa Hutchinson. Retrieved from http://www.opensecrets.org/lobby/lobbyist.php?id=Y0000041438L\&year=2007

Chuck, E. \& Johnson, M.A. (2012, December 22). Armed guards, locked entryways, cameras: Schools seek security after Sandy Hook. US News on NBCnews.com. Retrieved from http://usnews.nbcnews.com/_news/2012/12/22/16042916-armed-guards-lockedentryways-cameras-schools-seek-security-after-sandy-hook?lite. 
Cohn, A.M. (2012, December 21). Democrats condemn NRA proposal for armed guards in schools. The Hill (Web log comment). Retrieved from http://articles.baltimoresun.com/2012-12-28/news/bs-ed-schol-shootings20121227_1_gun-control-debate-gun-sales-gun-violence.

Congressional Budget Office. (2012, September 27). The proposed Homeland security budget for 2013. U.S Congress. Retrieved from http://www.cbo.gov/publication/43520.

Crews, G. \& Crews, A. (2013). Mondays and "Golden Rules”: Asking convicted school shooters about school violence. Conference paper presented at the Academy of Criminal Justice Sciences, Dallas, TX. March 31, 2013.

Crow, T. (2000). Crime prevention through environmental design, 2nd edition. Woburn, MA: Butterworth-Heinemann.

Department of Justice (2012, October 24). Justice Department files lawsuit in Mississippi to protect the constitutional rights of children. Retrieved from http://www.justice.gov/opa/pr/2012/October/12-crt-1281.html.

Dewey, C. (2011, December 20). Since Newtown school shootings, sales of bulletproof kids' backpacks soar. The Washington Post. Retrieved from http://www.washingtonpost.com/business/economy/sales-of-kids-bullet-proof-backpackssoar/2012/12/20/6cba668a-4a1e-11e2-820e-17eefac2f939_story_1.html.

Government Accountability Office (2010). Selected cases of public and private schools that hired or retained individuals with histories of sexual misconduct. GAO-11-200, K-12 Education. Retrieved from http://www.legistorm.com/showFile/L2xzX3Njb3J1L2dhby9wZGYvMjAxMC8xMg==/f u140834.pdf. 
Gray, R. H. (2013, February 4). Obama and the NRA's school security plans are both right....and wrong. Campus Safety: Campus Command Post. Retrieved from http://www.campussafetymagazine.com/Blog/Campus-CommandPost/Story/2013/02/Obama-and-the-NRA-Are-Both-Right-and-Wrong.aspx.

Grossman, D. (2013). Untitled keynote address to the West Virginia Safe Schools Summit, Charleston, WV. February 6, 2013.

Gubrecht, J. (2012, December 17). What really makes schools safer? CNN.com. Retrieved from http://www.cnn.com/2012/12/15/us/connecticut-school-safety.

Halbig, W. (2008, January 1). Architects must participate in school safety and security audits. Campus Safe: School Safety. Retrieved from http://www.campussafetymagazine.com/Channel/SchoolSafety/Articles/2008/01/Architects-Must-Participate-in-School-Safety-and-SecurityAudits.aspx.

Hendry, E. R. (2013, January 17). Survey: Majority of teachers don't want guns in Fairfax schools. McLean Patch. Retrieved from http://mclean.patch.com/articles/surveymajority-of-teachers-don-t-want-guns-in-fairfax-schools.

Huffington Post (2013, January 15). Guns in schools: Firearms already allowed in 18 states with few restrictions. Retrieved from http://www.huffingtonpost.com/2013/01/15/guns-inschools-firearms-_n_2482168.html.

Hutchinson, A. (2012, December 21). The National School Shield: NRA Education and Training Emergency Response Program [Press conference]. National Rifle Association, Washington, D.C. 
Hutchinson, A. (2012, December 23). 'This Week' transcript: Asa Hutchinson, Sen. Johnny Isakson and Sen. Amy Klobucher. ABC This Week. Retrieved from http://abcnews.go.com/Politics/week-transcript-asa-hutchinson-sen-johnny-isaksonsen/story?id=18044867.

Jennings, W. G., Khey, D. N., Maskaly, J., \& Donner, C. M. (2011). Evaluating the relationship between law enforcement and school security measures and violent crime in schools. Journal of Police Crisis Negotiations, 11, 109-124.

Johnson, L. (2013, January 3). Jeff Flake: NRA's Armed Guard Proposal would be 'edict from Washington.' The Huffington Post. Retrieved from http://www.huffingtonpost.com/2013/01/03/jeff-flake-nra_n_2402957.html.

Johnson, M. (2013, January 15). Guns already allowed in schools with little restriction in many states. The Open Channel: NBC News. Retrieved from http://openchannel.nbcnews.com/_news/2013/01/14/16468754-guns-already-allowed-inschools-with-little-restriction-in-many-states?lite.

Kelley, S. (2011, December 27). Confessions of a private security contractor. CNN.com Retrieved from http://security.blogs.cnn.com/2011/12/27/confessions-of-a-privatesecurity-contractor/.

Kimery, A. (2012, March 9). Security, port authorities associations urge DHS to reconsider port allocations. Homeland Security Today. Retrieved from http://www.hstoday.us/focusedtopics/counternarcotics-terrorism-intelligence/single-article-page/security-portauthorities-associations-urge-dhs-to-reconsider-port-allocations.html. 
Kupchik, A. (2012, December 30). The flaws in the NRA's school-security proposal. The Washington Post. Retrieved from http://articles.washingtonpost.com/2012-1230/opinions/36071256_1_school-resource-officers-police-officers-nypd-school-safetydivision.

Lang, L. (2005). No bullies on board: Putting the brakes on school bus bullying. American Public Health Association: School Health Education and Services. Retrieved from http://www.apha.org/membergroups/newsletters/sectionnewsletters/school/spring05/163. htm.

LaPierre, W. (2012, December 21). The National School Shield: NRA Education and Training Emergency Response Program. [Press conference]. National Rifle Association, Washington, D.C.

Lichtblau, E. \& Rich, M. (2012, December 22). NRA envisions 'a good guy with a gun' in every school. The New York Times. Retrieved from: http:/www.nytimes.com/2012/12/22/us/nra-calls-for-armed-guards-atschools.html?pagewanted=all\&_r=0.

Lohman, J. \& Shepard, A. (2006). School security technologies. OLR Research Report. State Department of Education, Hartford, CT.

McCann, R. (2010, August 19). 19 security officers arrested in 9 days! www.privateofficer.com. Private Officer News Network. Retrieved from http://privateofficernews.wordpress.com/category/ram/. 
McGreevy, P. (2013, February 1). California voters don't want armed teachers on campus, survey says. Los Angeles Times: PolitiCal. Retrieved from http:/latimesblogs.latimes.com/california-politics/2013/02/california-voters-dont-wantarmed-teachers-on-campus-survey-says.html.

McKinley, Jr., J.C. (2008). In Texas school, teachers carry books and guns. The New York Times. Retrieved from http://www.nytimes.com/2008/08/29/us/29texas.html?pagewanted=all.

Martino, M. (2012, March 7). Seaport experts urge congress to support port security grants, fully use maintenance tax and fund channel construction. American Association of Port Authorities. Retrieved from http://www.aapaports.org/Press/PRdetail.cfm?itemnumber=18434.

Murphy, T. (2013, January 8). NRA private security advocate works for private security company. Mother Jones. Retrieved from http://www.motherjones.com/politics/2013/01/asa-hutchinson-nra-pinkerton-securitaslobbyist.

Moore, D. (2012, December 28). Does the NRA have a point? Armed guards in schools have helped curb drug problem. New York Daily News. Retrieved from http://www.nydailynews.com/life-style/health/drugs-violence-schools-nra-point-article1.1228445 .

National Center for Injury Prevention and Control (2012). Understanding school violence: Fact sheet. Centers for Disease Control and Injury Prevention: Atlanta, GA. 
Neuman, S. (2012, March 16). Violence in schools: How big a problem is it? National Public Radio: Education. Retrieved from http://www.npr.org/2012/03/16/148758783/violencein-schools-how-big-a-problem-is-it.

Newman, K. (2004). Rampage: The social roots of school shootings. Basic Books: New York.

O’Brien, M. (2011, December 18). How much would it cost to put armed guards at every public school. The Atlantic. Retrieved from http://www.theatlantic.com/business/archive/2012/12/how-much-would-it-cost-to-putguards-with-guns-in-every-public-school/266579/.

Perry, T. (2001, October 30). Shooter in school rampage hangs himself in jail. Los Angeles Times. Retrieved from http://articles.latimes.com/2001/oct/30/local/me-63360.

Rich, M. (2011, December 21). School officials look again at security measures once dismissed. The New York Times. Retrieved from http://www.nytimes.com/2012/12/19/education/after-newtown-shootings-schoolsconsider-armed-security-officers.html?_r $=0$

Robers, S., Zhang, J., Truman, J., \& Synder, T.D. (2012). Indicators of school crime and safety, 2011. National Center for Education Statistics, U.S. Department of Education, and Bureau of Justice Statistics, Office of Justice Programs, U.S. Department of Justice. Washington, D.C. Retrieved from http://nces.ed.gov/pubs2012/2012002.pdf.

Skiba, R. (2013, January 26). Is putting armed guards in school a good idea? No. Newstimes.com Retrieved from http://www.newstimes.com/default/article/Is-putting-armed-guards-inschools-a-good-idea-4225936.php. 
Snyder, T.D. \& Dillow, S. A. (2012). Digest of Education Statistics: 2011 (NCES 2012-001). National Center for Education Statistics, Institute of Education Sciences, U.S. Department of Education. Washington, D.C.

Sullivan, S. (2012, December 21). NRA's Wayne LaPierre: Put 'armed police officers' in every school. The Washington Post. Retrieved from http://www.washingtonpost.com/blogs/post-politics/wp/2012/12/21/nras-wayne-lapierreput-armed-police-officers-in-every-school/.

Thomas, J.R. (2013, January 28). Poll: Teachers oppose carrying guns on campus. The CT Mirror. Retrieved from http://www.ctmirror.org/story/18911/poll-most-oppose-teacherscarrying-guns-campus.

Williams, M. (2012, December 21). NRA proposal to post armed guards in schools is debunked by critics. The Guardian. Retrieved from: http://www.guardian.co.uk/world/2012/dec/21/nra-armed-guards-schools.

Workman, D. (2012, December 21). NRA rips 'gun-free' zones, launches National School Safety Shield program. The Examiner. Retrieved from http://www.examiner.com/article/nra-rips-gun-free-zones-launches-national-schoolsafety-shield-program.

Zagorski, E. (2012, December 25). NRA suggestions for armed guards in schools gets mixed reviews locally. Baraboo New Republic. Retrieved from http://www.wiscnews.com/news/local/article_955a3944-4f0f-11e2-a8140019bb2963f4.html. 
Table 1

Advantages and Disadvantages of Trained, Armed Security Guards \& Community Volunteers

\begin{tabular}{|l|l|}
\hline \multicolumn{1}{|c|}{ Advantages } & \multicolumn{1}{|c|}{ Disadvantages } \\
\hline Decreased public fear & Increased potential for accidents \\
\hline Increased public perceptions of safety & False sense of security \\
\hline Quicker response time to incidents & Increased potential for civil and/or criminal liability \\
\hline Potential to intervene and prevent or reduce harm & Increased availability of weapons \\
\hline May dissuade less motivated potential offenders & Providing more people greater access to children \\
\hline Increased profits for security industry & Increased cost to school districts \\
\hline & Increased referrals to juvenile justice system \\
\hline & Decreased graduation rates/Increased dropouts \\
\hline & Increased fear and resentment among children \\
\hline & Potential negative impact on school climate \\
\hline & Potential diversion of law enforcement resources \\
\hline & Insurance and Worker's Compensation issues \\
\hline & Potential union conflicts \\
\hline
\end{tabular}

Table 1 
Table 2

Liability Issues Related to Armed Guards in Schools

Potential Liability

\section{Type of Officers}

On-duty, off-duty, retired public police officers

Current or former military/National Guard

Private security

Parents/Community Volunteers

Recruitment of Officers

Misrepresentation of duties

Selection of Officers

Criminal history checks

Drug testing

Psychological evaluations

Physical qualifications

Training of Officers

Firearms training

Criminal procedure dealing with juveniles Interviewing \& interrogating juveniles

Search \& seizure with juveniles

Detention/arrest of juveniles

Investigations in a school environment

Psychology of juveniles

Dealing with parents

Transporting/transferring juveniles

Juvenile petitions

Testifying in detention hearings

Supervision of Officers

Oversight of daily operations

Reporting of problems with officers

Duty or Failure to Act

Protect others or fail to protect others

Departmental Policies, Rules \& Regulations

Zero Tolerance versus Selective Enforcement

Potential for bias \& discrimination

Treatment of minor or school infractions

Access to Facilities

Rooms, equipment, records

Access to Children

Power \& authority

Abuse of trust

Personal Relationships with Children

Potential for bias (positive or negative)

Student Rights to Privacy
Who is Potentially Held Liable?

School Boards

Police Departments, School Boards, Private

Security Agencies, Consulting Firms

Police Departments, School Boards, Private

Security Agencies, Consulting Firms

Police Departments, Local or State Training

Academies, Private Security Agencies, Private

Consultants
Police Departments, Private Security Agencies, School Boards, Principals

Police Departments, Private Security Agencies, School Boards, Principals, Teachers, Individuals Police Departments, Private Security Agencies Police Departments, Private Security Agencies, School Boards, Principals, Individuals

Police Departments, Private Security Agencies, School Boards, Principals, Individuals

Police Departments, Private Security Agencies, School Boards, Principals, Individuals

Police Departments, Private Security Agencies, School Boards, Principals, Individuals

Police Departments, Private Security Agencies, School Boards, Principals, Teachers, Individuals

Table 2 